\title{
IMPACT OF COVID-19 ON THE COASTAL ENVIRONMENT AND ACTIVITIES AT KO YO, SONGKHLA, THAILAND
}

\author{
SinUTOK, S. ${ }^{1,2}-$ CHOTIKARN, P. ${ }^{1,2,3}-$ YUCHAROEN, M. ${ }^{1,2,3^{*}}$ \\ ${ }^{1}$ Faculty of Environmental Management, Prince of Songkla University, 90110 Songkhla, \\ Thailand \\ ${ }^{2}$ Coastal Oceanography and Climate Change Research Center, Prince of Songkla University, \\ 90110 Songkhla, Thailand \\ ${ }^{3}$ Marine and Coastal Resources Institute, Faculty of Environmental Management, Prince of \\ Songkla University, 90110 Songkhla, Thailand \\ *Corresponding author \\ e-mail: mathinee.y@psu.ac.th; phone+66-75-282-327; fax: +66-74-429-758
}

(Received $4^{\text {th }}$ Mar 2021; accepted $14^{\text {th }}$ May 2021)

\begin{abstract}
The Thailand national lockdown caused by the coronavirus pandemic lasted for several months. Ko Yo is one of the tourist attractions in Songkhla province due to its unique culture, environment, and businesses. The lockdown has changed the local lifestyle together with its socioeconomic and environmental impacts. This study aimed to integrally investigate the impacts of the COVID-19 related societal responses on the coastal environment and activities and the adaptive capacity of businesses on Ko Yo Island in Songkhla province. The results showed negative impacts of the COVID-19 on restaurants, homestays, and aquaculture businesses due to the Governmental emergency decrees. Aquaculture was the most affected business. Despite the reduced number of customers and transportation problems, some restaurants and homestays have provided delivery services and fishing areas as novel services available to their customers. The decrease in coastal activities had positively affected some environmental parameters, e.g., total nitrogen, total phosphorus, dissolved oxygen, and biochemical oxygen demand in water. In conclusion, businesses in Ko Yo were vulnerable to the disruption and the COVID-19 related situation. The local government organizations should seek to support the local communities, active businesses, and people in need to increase their adaptive capacities by providing financial support, organizing career development workshops, and coordinating and counseling local people. Short and long terms of emergency measures should be set at upper levels of government.
\end{abstract}

Keywords: global pandemic, socioeconomic effects, environmental effects, local Thailand

\section{Introduction}

The COVID-19 pandemic has rapidly spread worldwide, beginning from China, and has impacted several human societies and economics (Corlett et al., 2020; Wang et al., 2020). Lockdowns have been implemented both internationally and within many countries (Lim et al., 2020). In Thailand, transportation was restricted, while in southern Thailand, the borders of Songkhla Province were controlled since late March 2020. That command prohibited all entry in or out of Songkhla, except for some necessary/essential cases. Later on, restaurants, department stores, markets, hotels, and local services were ordered to shut down (Songkhla Provincial Government Center, 2020).

Ko Yo is an island in the lower Songkhla lagoon with a total area of $15 \mathrm{~km}^{2}$, divided into nine villages (Promprasit et al., 2013), and is an economical tourist attraction in the Songkhla province. Ko Yo has established an agricultural tourist club since 2000 (Thammachot, 2006) that has integrated occupations (more than 200 entrepreneurs) 
from both large- and small-scale agricultural, fishery, and cottage industry businesses (Sutas Na-Ayuthaya, 2017). The coast of the peninsular is protected by hard constructions such as revetments, wave breakers where natural resources remain functional and essential for the local community. For example, the mangrove habitats and fisheries are highly important to Ko Yo's local community (Department of Marine and Coastal Resources, 2020).

Due to the Songkhla lockdown, most businesses have been closed for about two months, including those on Ko Yo. The local livelihoods were suddenly affected, with the loss of jobs and food security associated with this unique culture and environment. Hence, this study was conducted to examine the impacts of the COVID-19 pandemic on Ko Yo's coastal activities. The negative and/or positive consequences associated with the COVID19 restrictions were assessed in relation to the vulnerability of the local communities to the disruption and the physical, chemical, and biological factors of the environment.

\section{Methodology}

Both interview and environment surveys ended during 5-15 May 2020, Ko Yo, Songkla, Thailand. The conceptual framework (Fig. 1) involved both social and science aspects: 1) socioeconomic in the main types of local businesses around Ko Yo, i.e., restaurants, homestays, and aquaculture; and 2) environmental surveys at three main stations (Table Al in the Appendix) with five sampling sites at varying distances from Ko Yo coast (Fig. 2).

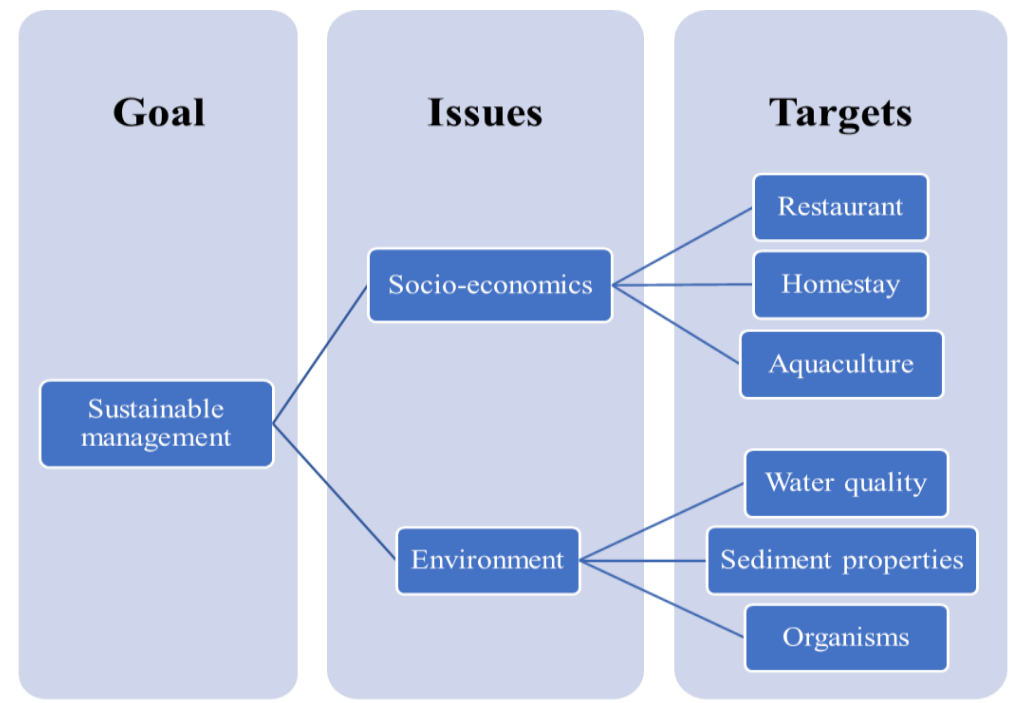

Figure 1. Theoretical framework of this study for determining impacts of the COVID-19 situation on Ko Yo's coastal activities

\section{Socio-economic observation}

The representative sampling was calculated from a total of 133 local businesses; 66 restaurants, 40 homestays, and 27 aquaculture cages using Taro Yamane formula as follows:

$$
n=\frac{N}{1+N e^{2}}
$$


in which " $n$ " is the sample size, " $N$ " is the population size, and " $e$ " is the error of the allowable randomized sample. The samples $(\mathrm{n}=33)$ were randomly investigated from local entrepreneurs as key informants. Both structured and semi-structured interviews were done to deploy a questionnaire (Table A2) during May 2020, when the lockdown was still restrictive. The questionnaire was related to four main issues; 1) general information of respondents, 2) effects of the COVID-19 pandemic on income and employment, 3) entrepreneur's adaptations to the COVID-19 crisis in terms of prevention of the spread of the epidemic, marketing/sale strategies, and new normal operations, 4) accessibility of aid measures from various agencies, (in)applicability of various government projects, and proposing aid measure requirements. Respondents provided all the economic data.

\section{Environmental survey}

The water, sediment, and aquatic plants were sampled (Strickland and Parsons, 1972; Boyd, 1990; American Public Health Association, 1992) at three stations on 29-31 May 2019 and 5-7 May 2020 to compare the apparent impacts of the COVID-19 pandemic. For each coastal station, there were five sampling sites in the lake at different distances from each other (Fig. 2), and at each sampling site, three replicate samples were collected. The temperature and $\mathrm{pH}$ were in-situ measured using YSI Professional Plus Multiparameter (YSI Incorporated, USA). The Secchi Disk was used for transparency. Water samples were collected by Kemmerer Water Sampler (Wildlife Supply Company, USA) for further laboratory analyses of total nitrogen (TN), total phosphorus (TP), dissolved oxygen (DO), and biochemical oxygen demand (BOD). Sediment samples were collected using a Birge-Ekman grab (Wildlife Supply Company, USA). All collected sediment samples were kept at $-20{ }^{\circ} \mathrm{C}$ and afterward analyzed for organic matter and organic carbon. Organic carbon analysis was determined by analyzing elements $\mathrm{C}, \mathrm{H}$, and $\mathrm{N}$ (Carlo Erba, EA-1106 model) followed by Verardo et al. (1990).

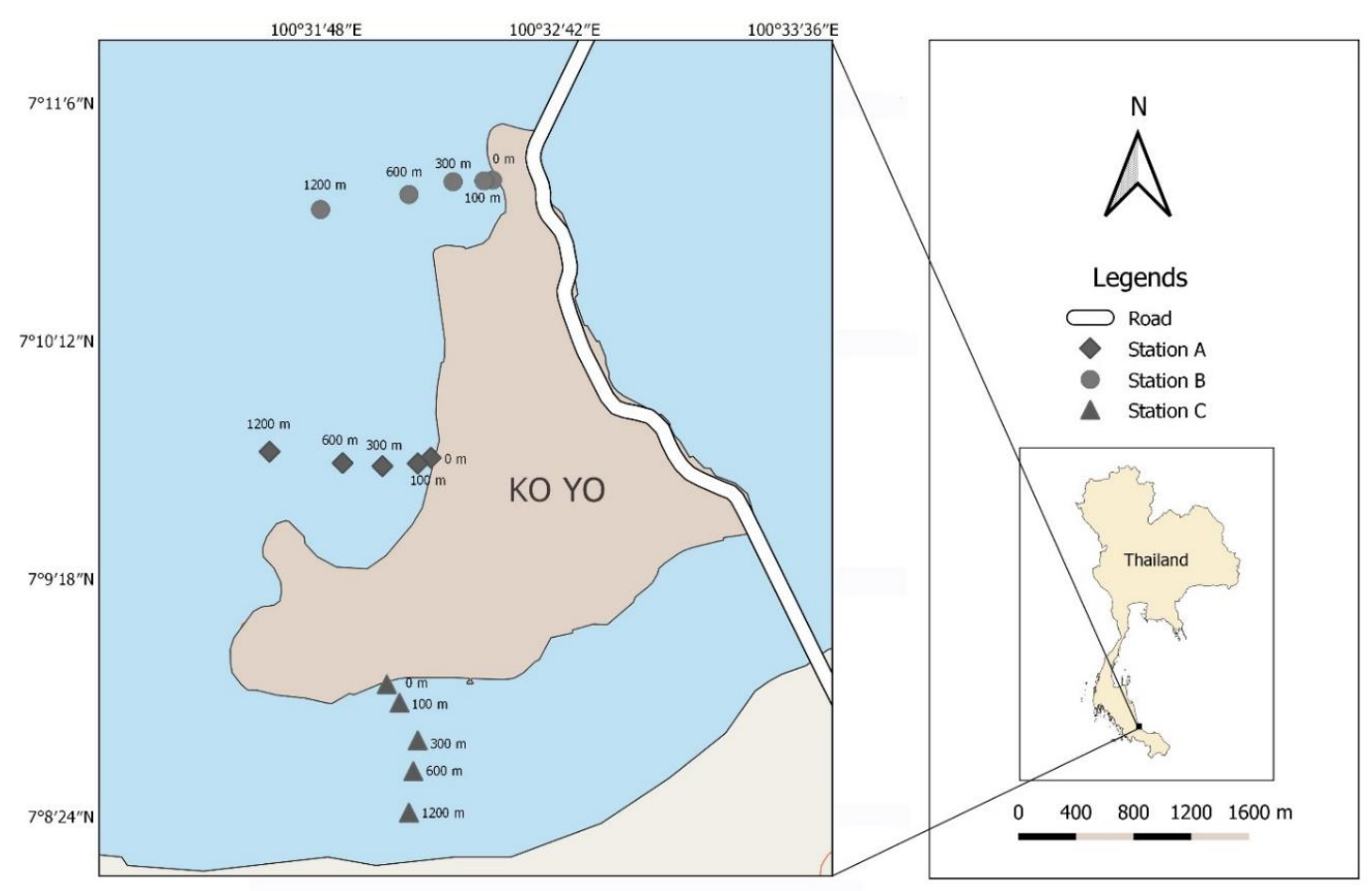

Figure 2. The A, B, and C coastal stations on Ko Yo, Songkhla, Thailand with five sampling sites in the lake at different distances from each other 


\section{Data analyses}

The multiple-choice data from the questionnaire were analyzed for frequencies and percentages at nominal and ordinal scales to test the hypothesis in each variable. The environmental data were subjected to Levene's and Kolmogorov-Smirnov tests for homogeneity of variance and normality, respectively. The t-test was used at the confidence level of $95 \%$ to compare time changes in each environmental parameter.

\section{Results}

\section{Effects of the COVID-19 pandemic on local businesses}

The COVID-19 pandemic mainly affected local businesses via marketing, such as order cancellations, customer loss, and absence of middleman, for $76.9 \%, 52.6 \%$, and $39.1 \%$ of businesses operating aquaculture, homestays, and restaurants (Fig. 3a). The following obstacles were in finances and labor, whereas the lockdown impacted manufacturers, logistics, and other activity losses only caused minor trouble to the local businesses. In all cases, the questionnaire responses indicate a loss of income. A complete $100 \%$ of critical decreases were reported by homestays and aquaculture businesses, while restaurants showed more diverse and less extreme results: $36.4 \%, 36.4 \%$, and $27.3 \%$ for critical, severe, and middle decreases, respectively (Fig. $3 b$ ). As a consequence of the COVID19 pandemic effects, some owners needed to let some employees go this impacted the employment rate, mainly by homestays that represented $72.7 \%$ of the critical decrease cases. However, there were many local businesses without changes in employment, especially those without employees (Fig. 3c). Moreover, we investigated the interviewee's expectations of their income in the next six months. In total, $75 \%$ of all local business owners predicted a definite future decline (Fig. 4).

a)
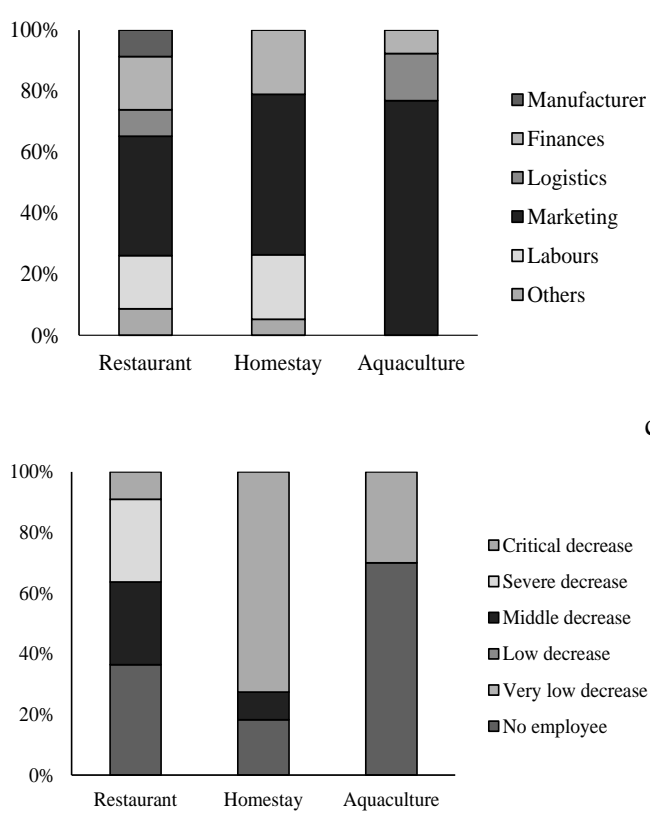

c)

$\square$ Critical decrease

$\square$ Severe decrease

- Middle decrease

口Low decrease

$\square$ Very low decrease

$\square$ No employee

$$
1
$$

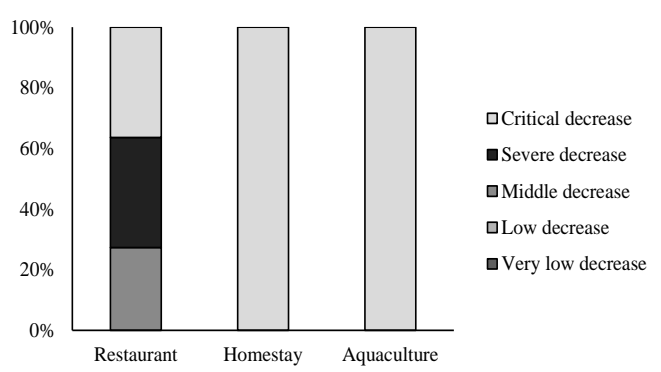

Figure 3. Frequency percentages among the local businesses $(n=33)$ affected by the COVID-19 pandemic during May 2020; a) obstacles for business operation, b) income reduction, and c) employment 


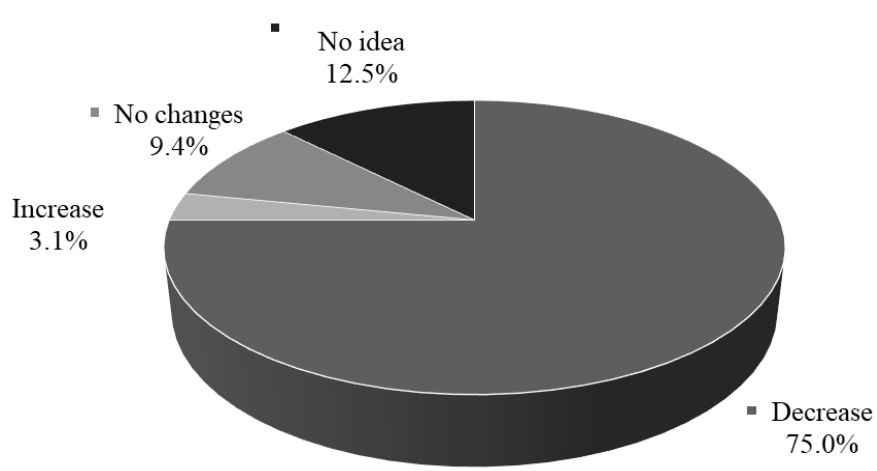

Figure 4. Percentages of future expectations regarding income in the next 6 months from May $2020(n=33)$

\section{Adaptive strategies to the COVID-19 crisis}

With the outbreak prevention, $96.9 \%$ of all the local businesses have followed the standard procedures to protect themselves and customers from the COVID-19 virus. The primary methods were provided (Fig. $5 a$ ) as use of alcohol gel or spray (47.6\%), surgery or fabric mask (39.7\%), and other measures, such as controlling customer numbers and distancing by limited seating. Several owners have adapted to sustain their businesses (Fig. 5b). All business types generally pursued the reduced salary/workforce and productivity cost savings. Various strategies of additional services were also observed; the restaurants provided take-home or delivery $(28.6 \%)$; the homestays provided customer attractions or promotions (21.4\%); the aquacultures delivered their products to events $(60 \%)$ instead of to walk-in customers and minor groups. Markedly, some restaurants (4.8\%), homestays (50\%), and aquacultures (30\%) completely stopped operation. As seen in Figure 5c, a large proportion of entrepreneurs expect to operate later under a new normal situation, and some would improve their strategies, especially the homestays (27.3\%). However, only a few aquaculture businesses would consider ceasing operations.

\section{Accessibility of aid measures}

According to the "Kon Thai Mai Ting Kan" government aid measure, restaurants were the leading target group. Of them, $45 \%$ could register and get financial aid, but $18.2 \%$ could not successfully register. On the other hand, the local homestays and aquacultures were mainly not registered for aid (Fig. 6a). Additionally, there were other kinds of assistance, for instance, the retention or reduction of rental fee or deposit, materials for the COVID-19 prevention from various organizations. Nevertheless, more than half of the interviewees did not receive any assistance (Fig. $6 b$ ).

\section{Environmental parameters}

The physical, chemical, and biological parameters of the water observed at the study sites were significantly changed in one year (paired t-test, $p<0.05$, Table 1 ). The temperature, total dissolved solids, dissolved oxygen, and chlorophyll- $a$ increased, whereas salinity, total nitrogen, total phosphorus, and biological oxygen demand were lower than before the COVID 19 pandemic (Fig. 7). The water $\mathrm{pH}$ and transparency showed steady values. Similar to sediment quality, the organic matter and organic carbon appeared constant across the sampling times (Fig. 8). 
Table 1. Statistical analysis by paired t-test comparing environmental parameters at two sampling times (2010 and 2020)

\begin{tabular}{c|c|c|c|c}
\hline Parameter & Df & Mean & t & $\boldsymbol{p}$-value \\
\hline Temperature $\left({ }^{\circ} \mathrm{C}\right)$ & 14 & -0.570 & -2.563 & $0.023^{*}$ \\
$\mathrm{pH}$ & 14 & -0.018 & -0.405 & 0.692 \\
Transparency $(\mathrm{m})$ & 14 & 0.050 & 0.660 & 0.520 \\
Total nitrogen $(\mathrm{mg}-\mathrm{N} / \mathrm{l})$ & 14 & 2.291 & 14.984 & $<0.001^{*}$ \\
Total phosphorus $(\mathrm{mg}-\mathrm{P} / \mathrm{l})$ & 14 & 0.022 & 4.385 & $0.001^{*}$ \\
Dissolved oxygen $(\mathrm{mg} / \mathrm{l})$ & 14 & -2.023 & -5.698 & $<0.001^{*}$ \\
Biological oxygen demand (mg/l) & 14 & 1.097 & 5.115 & $<0.001^{*}$ \\
Organic matter $(\%)$ & 14 & -0.754 & -1.045 & 0.314 \\
Organic carbon $(\%)$ & 14 & -0.196 & -0.419 & 0.682 \\
\hline
\end{tabular}

a)
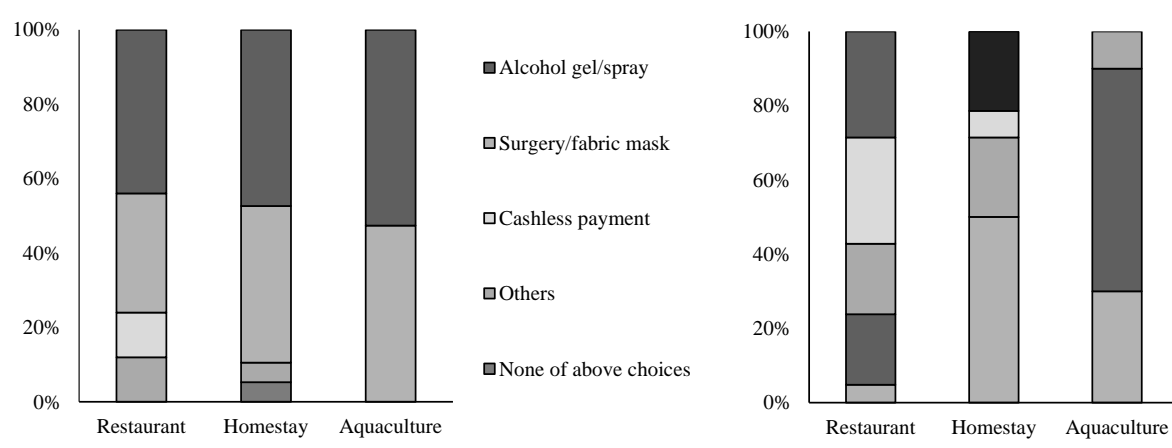

c)

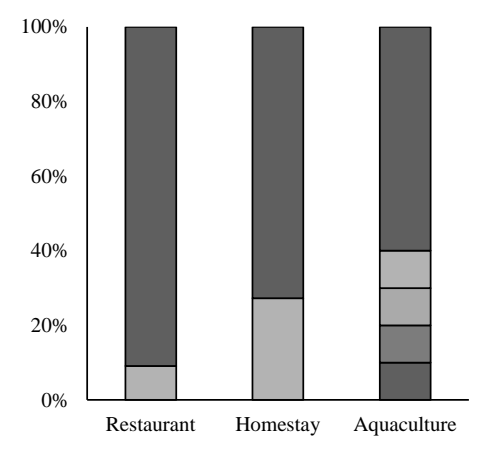

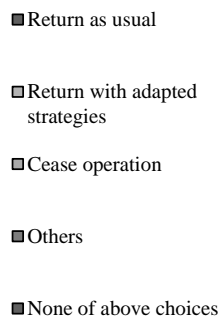

घNone of above choices

Figure 5. Frequencies (percentages) within each type of the local business ( $n=33$ ) adapted to the COVID-19 pandemic during May 2020: a) outbreak prevention, b) adaptive process, and c) future expectation in new normal situation

\section{Discussion}

Undoubtedly, the local entrepreneurs on Ko Yo island were seriously affected by the COVID-19 pandemic (or the societal responses to it), primarily via marketing issues and loss of income. Since Ko Yo is relatively far from the main local population centers for delivery service, and the major customers used to be foreign tourists, the restaurants have previously operated for dine-in only. Losing foreign tourism had various domino effects. The aquaculture businesses were unable to continue operating mainly as suppliers 
to the local restaurants. Moreover, the operations of physical markets and middlemen were disrupted as well. At the same time, homestays were temporarily closed due to the government's emergency measures. Another critical factor is that most local owners decided to temporarily lay employees off and cut their expenses rather than adapting to online platforms and digital marketing. Very few of the restaurants pursued their online marketing options. Overall, there was a severe impact on Ko Yo's local economy. Globally, the whole supply chain and production linkages have been disrupted by responses to the epidemic (Gregorioa and Ancog, 2020; Hasanat et al., 2020; McKibbin and Fernando, 2020; Ozili and Arun, 2020). Although it is difficult for the local people to master digital technology, they at least made an effort to create extra services, such as delivery. Longterm impacts are strongly expected, as our results on the business owners' expectations of income indicated potential recovery only after 1-2 years. There have also been several indirect effects of the COVID-19 lockdown, particularly in developing countries with high population densities: food shortages, psychological trauma, and reduced access to health care (Danylyshyn, 2020; Laborde et al., 2020; Loayza, 2020; McIntyre and Lee, 2020; Nochaiwong et al., 2020).

a)

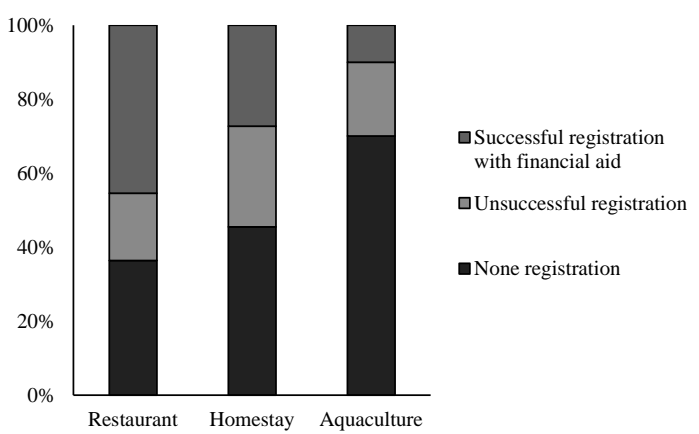

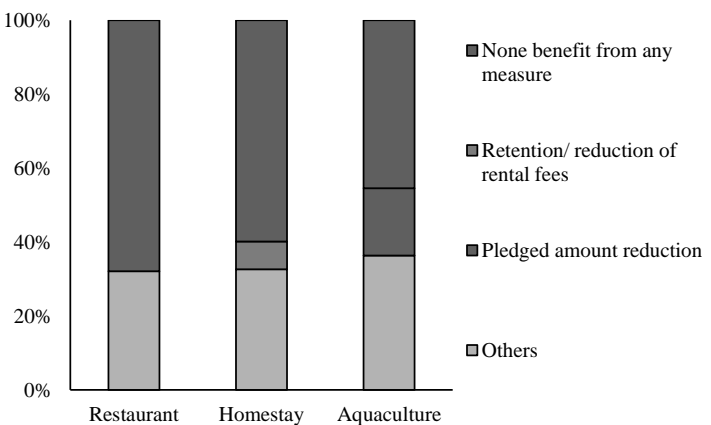

Figure 6. Frequencies (percentages) among each type of local business $(n=33)$ concerning aid measures during the COVID-19 pandemic on May 2020: a) Kon Thai Mai Ting Kan project of the government aid measure, and $b$ ) other types of assistance

It was laudable that most people on Ko Yo demonstrated awareness and active prevention measures against the pandemic. The Thailand Public Health had rapid responses to COVID19 tracing, daily reporting, quarantine restrictions, and public education (Doung-Ngern et al., 2020). Regarding the aid measures, less than half of Ko Yo entrepreneurs got any financial benefits. It should be noted that the government aid projects were implemented on digital platforms, and this could be a barrier to the locals or elderly people. Nevertheless, there were other forms of support, such as reduction or cancellation of electricity bill, water bill, waste disposal bill, along with a tax reduction. There was also a proposal from local entrepreneurs to request specific mitigations, markets, or channels for their export products and helping skills development or supporting alternative jobs. 
a)

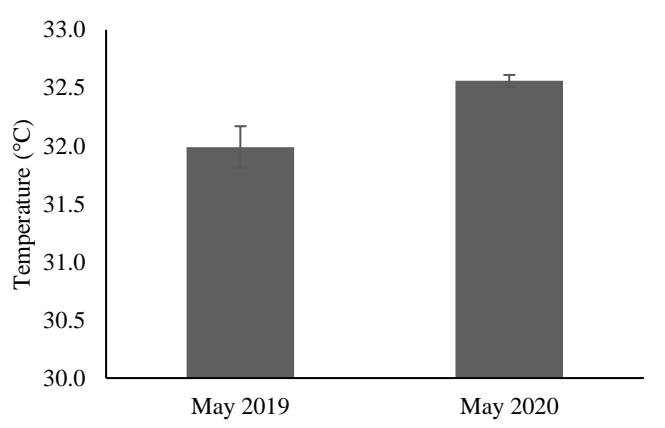

c)

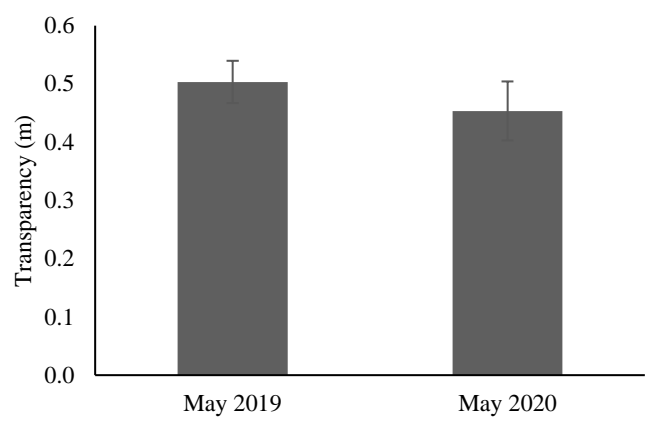

e)

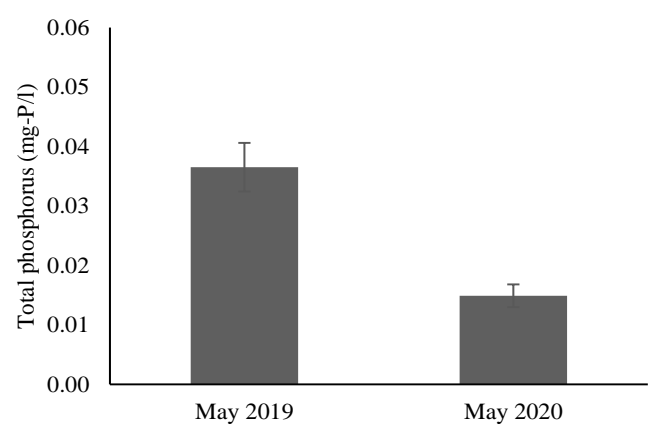

g)

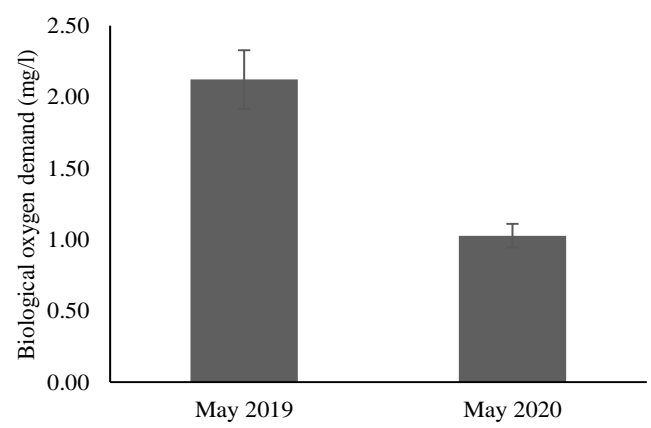

b)

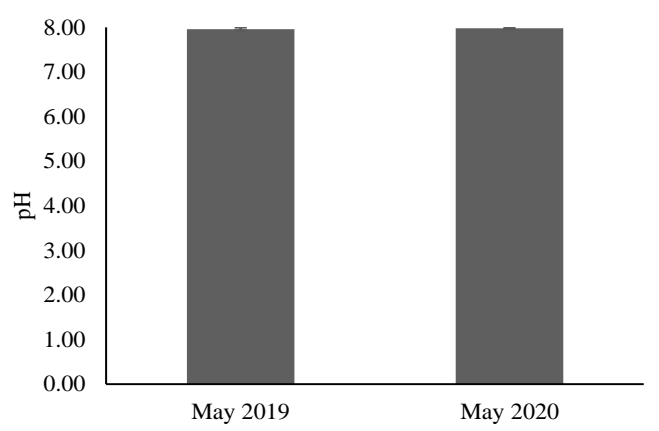

d)

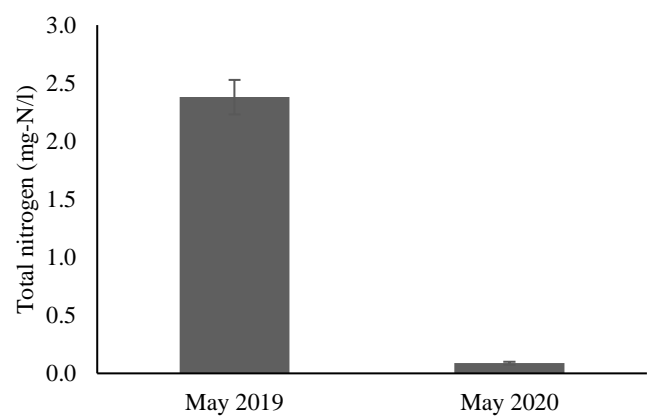

f)

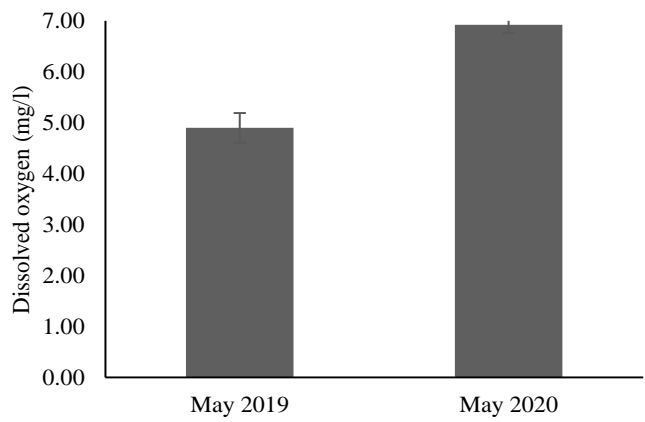

Figure 7. Physical parameters of water (mean $\pm S E$ ); a) temperature, $b) p H$, and c) transparency, chemical and biological parameters; d) total nitrogen, e) total phosphorus, $f$ ) dissolved oxygen, and g) biological oxygen demand 
Regarding environmental impacts, there were no significant differences $(p>0.05)$ in transparency or $\mathrm{pH}$ of the water body around Ko Yo. In contrast, temperature, TN, TP, and BOD before the COVID-19 crisis (May 2019) were significantly higher $(p>0.05)$ than during the pandemic (May 2020), while DO was significantly lower. However, an increase in temperature in May 2020 could not be related to human activities. TN and TP are water nutrients that play natural roles in nitrogen and phosphorus cycles. Another important source is sewage from the community, for example, wash waters and food residues (Regional Environment Office 16 (Songkhla), 2009; Pradit et al., 2010). Extremely high TN and TP will cause plankton bloom. BOD is the amount of oxygen used by microorganisms to decompose organic matter; too high BOD will spoil the water. In this study, TN, TP, and BOD in May 2020 were lower than in May 2019. This might be due to temporarily suspended or reduced anthropogenic activities, especially in businesses during COVID-19 (March-May 2020), and reduced sewage release. Nonetheless, TN in May 2019 and 2020 was still in the standard range of seawater quality for standard type $1(0.020 \mathrm{mg}-\mathrm{N} / \mathrm{l})$ and types 3 and $6(0.060 \mathrm{mg}-\mathrm{N} / \mathrm{l})$. TP in May of 2019 and of 2020 was also in the standard range of seawater quality standard type $1(0.015 \mathrm{mg}-\mathrm{P} / \mathrm{l})$ and types 3 and 6 (0.045 mg-P/l). Furthermore, BOD in May of 2019 and of 2020 was in standard level for sewage control from the municipal wastewater treatment system and standards for wastewater discharge control from coastal aquaculture ponds, at less than $20 \mathrm{mg} / \mathrm{l}$ (Pollution Control Department, 2020). Dissolved oxygen at both these sampling times was still in the standard range of $5-8 \mathrm{mg} / \mathrm{l}$. For wastewater, dissolved oxygen was less than $3 \mathrm{mg} / \mathrm{l}$ (Pollution Control Department, 2020).

a)

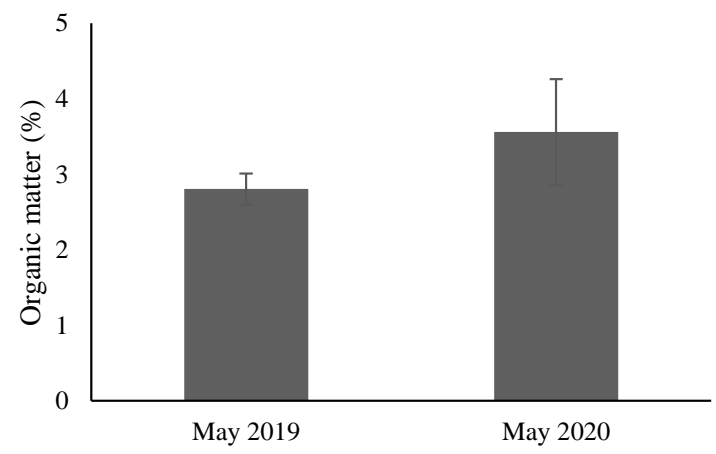

b)

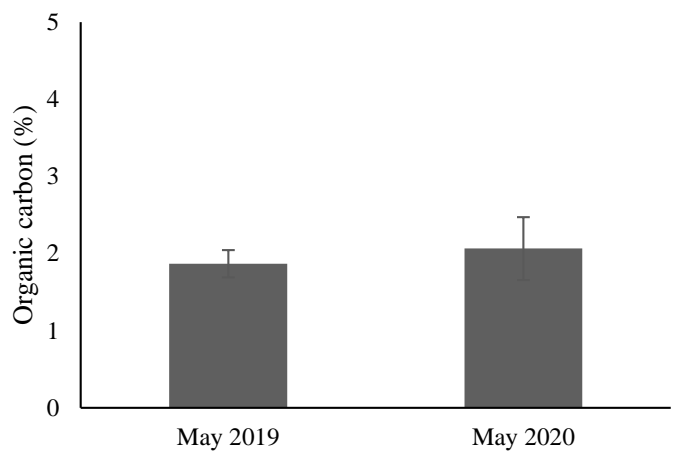

Figure 8. Sediment quality (mean $\pm S E$ ); a) organic matter, and b) organic carbon (\%) in sediment

Additionally, there were no significant differences in organic matter or organic carbon of sediments between May of 2019 and May of 2020 (P > 0.05). The amount of organic matter arises from residues of plant, animal, and microbial cells, either alive or dead (Meksumpan, 2005), or even from waste discharge from the community sources such as homestays, houses built in seaward, and discharge of fecal waste or food waste into the seawater. There are sea perch cultures in cages, fed with fresh fish, and the food remains will settle down to the bottom. This contributes to organic matter content in the sediment. Therefore, during the COVID-19 outbreak affecting the trade of sea perch by prevented trading, the villagers needed to culture the sea perch continuously. Despite no activities during these two months, no change in organic matter or organic carbon was seen. 


\section{Recommendations}

The health tourism business will likely grow and will be a competitive advantage for the country. Based on this vision, we suggest management policies to appropriate authorities for the sustainable economic development of the community through local resources and benefit to the resource management by government organizations, according to the Thailand 4.0 policy. Furthermore, this policy suggestion conforms to the National Development Strategy following the 12th National Economic and Social Development Plan (2017-2020) in the eco-friendly growth strategy for sustainable development by preserving natural resources' preservation and restoration guidelines for proper conservation and utilization.

1. Relevant agencies should organize training to develop professional knowledge and skills in digital marketing, fishery and agricultural product processing, and other local production, emphasizing eco-friendly products and the management of health and ecosustainable tourism.

2. Related departments should coordinate, assist, and advise people in various areas, such as in registration, to receive project funds; and serve as distribution centers to educate on adaptation and coping with the COVID-19 virus and distribute essential information equipment for disease prevention.

\section{Conclusion}

The COVID-19 pandemic negatively impacted all three main types of business on Ko Yo island, namely restaurants, homestays, and aquaculture businesses. There was a butterfly effect with loss of customers, causing lack of income and emergency measures of the government disrupting operations. Meanwhile, employment suffered, and sea perch could no longer be sold to the nearby restaurants. Some entrepreneurs adapted to new services providing opportunities, but only in a few cases. The most affected by this crisis with no adaptation was aquaculture (mainly sea perch culture). This study suggests that Ko Yo businesses are vulnerable to this type of crisis, and there should be a risk management plan for coping with future crises or disasters. However, the reduced coastal activity on Ko Yo positively affected the water quality in terms of DO, BOD, TN, and TP that showed improvements from before the COVID-19 situation. Future studies on the indirect, longterm, and macro-level impacts of multiple waves of COVID-19 situation on socio-economy and environment and the adaptive capacity of local communities should be done.

Acknowledgements. This research was funded by Faculty of Environmental Management Research Fund (ENV6304125d). The authors thank Research and Development Office, Prince of Songkla University, Assoc. Prof. Dr. Seppo Karrila, and Dr. Chitra Ramphul for assistance with proofing the English.

\section{REFERENCES}

[1] American Public Health Association (1992): Standard Methods for the Examination of Water and Wastewater. $18^{\text {th }}$ Ed. - American Public Health Association, Washington, DC, pp. 4-87.

[2] Boyd, C. E. (1990): Water Quality in Pond for Aquaculture. - Alabama Agricultural Experiment Station, Auburn University, Alabama, pp. 1-35.

[3] Corlett, R. T., Primack, R. B., Devictor, V., Maas, B., Goswami, V. R., Bates, A. E., Koh, L. P., Regan, T. J., Loyola, R., Pakeman, R. J., Cumming, G. S., Pidgeon, A., Johns, D., 
Roth, R. (2020): Impacts of the coronavirus pandemic on biodiversity conservation. Biological Conservation 246: 108571.

[4] Danylyshyn, B. (2020): The peculiarities of economic crisis due to COVID-19 pandemic in a developing country: case of Ukraine. - Problems and Perspectives in Management 18(2): 13-22.

[5] Department of Marine and Coastal Resources (2020): DMCR News: Ko Yo Coastline, Songkhla Maintain Natural Balance. - https://www.dmcr.go.th/detailAll/38356/ nws/22 (4 August 2020).

[6] Doung-Ngern, P., Suphanchaimat, R., Panjangampatthana, A., Janekrongtham, C., Ruampoom, D., Daochaeng, N., Eungkanit, N., Pisitpayat, N., Srisong, N., Yasopa, O., Plernprom, P., Promduangsi, P., Kumphon, P., Suangtho, P., Watakulsin, P., Chaiya, S., Kripattanapong, S., Chantian, T., Bloss, E., Namwat, C., Limmathurotsakul, D. (2020): Case-control study of use of personal protective measures and risk for SARS-CoV 2 infection, Thailand. Emerging Infectious Diseases 26(11): 2607-2616.

[7] Gregorioa, G. B., Ancog, R. C. (2020): Assessing the impact of the COVID-19 pandemic on agricultural production in Southeast Asia: toward transformative change in agricultural food systems. - Asian Journal of Agriculture and Development, Southeast Asian Regional Center for Graduate Study and Research in Agriculture (SEARCA) 17(1): 1-13.

[8] Hasanat, M. W., Hoque, A., Shikha, F. A., Anwar, M., Hamid, A. B. A., Huam, T. H. (2020): The impact of coronavirus (COVID-19) on e-business in Malaysia. - Asian Journal of Multidisciplinary Studies 3(1): 85-90.

[9] Laborde, D., Martin, W., Vos, R. (2020): Poverty and Food Insecurity Could Grow Dramatically as COVID-19 Spreads. - International Food Policy Research Institute. https://www.ifpri.org/ blog/poverty-and-food-insecurity-could-grow-dramatically- covid-19-spreads.

[10] Lim, W. S., Liang, C. K., Assantachai, P., Auyeung, T. W., Kang, L., Lee, W., Lim, J., Sugimoto, K., Akishita, M., Chia, S., Chou, M., Ding, Y., Iijima, K., Jang, H. C., Kawashima, S., Kim, M., Kojima, T., Kuzuya, M., Lee, J., Lee, S., Lee, Y., Peng, L., Wang, N., Wang, Y., Won, C. W., Woo, J., Chen, L., Arai, H. (2020): COVID-19 and older people in Asia: Asian Working Group for Sarcopenia calls to actions. - Geriatrics and Gerontology International 20(6): 547-558.

[11] Loayza, N. V. (2020): Costs and Trade-Offs in the Fight Against the COVID-19 Pandemic: A Developing Country Perspective. - World Bank Research \& Policy Briefs No.35.

[12] McIntyre, R. S., Lee, Y. (2020): Projected increases in suicide in Canada as a consequence of COVID-19. - Psychiatry Research 290: 113104.

[13] McKibbin, W. J., Fernando, R. (2020): The Global Macroeconomic Impacts of COVID19: Seven Scenarios (March 2, 2020). - Centre for Applied Macroeconomic Analysis (CAMA) Working Paper No. 19/2020.

[14] Meksumpan, J. (2005): Sediments. - Department of Fishery Biology, Faculty of Fisheries, Kasetsart University, Bangkok, pp. 7-86.

[15] Nochaiwong, S., Ruengorn, C., Awiphan, R., Ruanta, Y., Boonchieng, W., Nanta, S., Kowatcharakul, W., Pumpaisalchai, W., Kanjanarat, P., Mongkhon, P., Thavorn, K., Hutton, B., Wongpakaran, N., Wongpakaran, T. (2020): Mental health circumstances among health care workers and general public under the pandemic situation of COVID-19 (HOME-COVID-19). - Medicine 99(26), e20751.

[16] Ozili, P. K., Arun, T. (2020): Spillover of COVID-19: Impact on the Global Economy. - SSRN. https://ssrn.com/abstract=3562570 or http://dx.doi.org/10.2139/ssrn. 3562570 .

[17] Pollution Control Department (2020): Seawater Quality Standard. - http://www.pcd.go.th/ info_serv/reg_std_water02.html.

[18] Pradit, S., Wattayakorn, G., Angsupanich, S., Baeyens, W., Leermakers, M. (2010): Distribution of trace elements in sediments and biota of Songkhla Lake, Southern Thailand. - Water Air and Soil Pollution 206: 155-174. 
[19] Promprasit, N., Pramojanee, S., Promsaka Na Sakolnakorn, T. (2013): The Problems of Agro-Tourism in Koh Yor, Muang district, Songkhla province. - 4th Hat Yai Academic Conference on 10 May 2013 at Hat Yai University, Hat Yai District, Songkhla Province, pp. 8-13.

[20] Regional Environment Office 16 (Songkhla) (2009): Situation of Natural Resources and Environment and Solutions to the Main Problems of Songkhla Lake Basin. - Office of the Permanent Secretary, Ministry of Natural Resources and Environment, Bangkok.

[21] Regional Environment Office 16 (Songkhla) (2020): Environmental Situation Report 2019 (Songkhla, Satun, Pattani, Yala and Narathiwat Provinces). - Office of the Permanent Secretary Natural Resources and Environment, Bangkok, pp. 3-1-3-34.

[22] Songkhla Provincial Government Center (2020): Announcements and Orders. - https://covid. songkhla.go.th/announce (22 Oct 2020).

[23] Strickland, J. D. H., Parsons, T. R. (1972): A Practical Handbook of Seawater Analysis. - Fisheries Research Board of Canada, Ottawa.

[24] Sutas Na-Ayuthaya, B. (2017): Annual Tumbon Development Report (TDR) Year 2017 Koh Yor Sub-District, Muang District, Songkhla Province. - Muang Songkhla District Community Development Office, Songkhla, pp. 1-28.

[25] Thammachot, Y. (2006): The Management Guidelines of Koh Yor's Agro Tourism Muang District Songkhla Province. - Mahidol University, Bangkok.

[26] United Nations (2020): Shared Responsibility, Global Solidarity: Responding to the SocioEconomic Impacts of COVID-19. - United Nations, New York.

[27] Verardo, D. J., Froelich, P. N., McIntyre, A. (1990): Determination of organic carbon and nitrogen in marine sediments using the Carlo Erba NA-1500 analyzer. Deep-sea research Part A. - Oceanographic Research Papers 37: 157-165.

[28] Wang, C., Horby, P. W., Hayden, F. G., Gao, G. F. (2020): A novel coronavirus outbreak of global health concern. - The Lancet 395(10223): 470-473.

\section{APPENDIX}

Table A1. The study site locations of environmental sampling

\begin{tabular}{c|c|c|c}
\hline Station & Distance from coast $(\mathbf{m})$ & Latitude & Longitude \\
\hline & 0 & 7.180164 & 100.5412 \\
& 100 & 7.180104 & 100.5407 \\
$\mathrm{~A}$ & 300 & 7.180049 & 100.5388 \\
& 600 & 7.179247 & 100.5361 \\
& 1,200 & 7.178298 & 100.5305 \\
\hline & 0 & 7.162629 & 100.5374 \\
$\mathrm{~B}$ & 100 & 7.162275 & 100.5365 \\
& 300 & 7.162107 & 100.5342 \\
& 600 & 7.162297 & 100.5318 \\
& 1,200 & 7.164205 & 100.5273 \\
\hline & 0 & 7.148349 & 100.5347 \\
$\mathrm{C}$ & 100 & 7.14762 & 100.5340 \\
& 300 & 7.144795 & 100.5365 \\
& 600 & 7.142855 & 100.5363 \\
& 1,200 & 7.140248 & 100.5360 \\
\hline
\end{tabular}


Table A2. The questionnaire using for socio-economic data

\begin{tabular}{l|l|l}
\hline \multicolumn{1}{c|}{ Question } & Answer & \multicolumn{1}{c}{ Remark } \\
\hline Part I General information & & \\
\hline - Name of company & & \\
- Type of business & & \\
- The number of people in household & & \\
- Annual income before COVID-19 & & \\
- Annual income during COVID-19 & & \\
pandemic effect & & \\
\hline
\end{tabular}

Part II Effects of the COVID-19 pandemic on income and employment

$\square$ Manufacturer Such as, the place

origin cannot produce raw materials/raw

materials cannot be delivered from the

epidemic area

$\square$ Finances Such as, there are still costs, and working capital can be insufficient

in the next 3 to 6 months

$\square$ Logistics Such as, transport must

- What obstacles have you encountered in pass through the epidemic area your business after COVID-19? (can choose one or more than one)

$\square$ Marketing Such as, customer cancels the orders, the number of customers decreased, lack of middleman $\square$ Technology Such as, lack of technology or experience to adapt to an online system

$\square$ Labor Such as, taking care of employees during the epidemic

$\square$ Other, specific.

- Income during COVID-19 pandemic compared to the same period last year

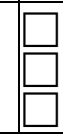

$\square$ Decrease (answer next question)

$\square$ Increase (jump next question)

$\square$ No change (jump next question)

- Please estimate the percentage of reducing income. (The monthly income compared to the same period of last year)

- The number of employments in your business

- Please estimate the percentage of employment that being reduced

- What do you predict about the income in the next 6 months of your business?

\begin{tabular}{|l|l}
$\square$ No change (jump next question) & \\
$\square 1 \%-20 \%$ & \\
$\square 21 \%-40 \%$ & \\
$\square 41 \%-60 \%$ & \\
$\square 61 \%-80 \%$ & \\
$\square 81 \%-100 \%$ & \\
$\square$ Decrease (answer next question) & \\
$\square$ Increase (jump next question) & \\
$\square$ No change (jump next question) & \\
$\square 1 \%-20 \%$ & \\
$\square 21 \%-40 \%$ & \\
$\square 41 \%-60 \%$ & \\
$\square 61 \%-80 \%$ & \\
$\square 81 \%$ - $100 \%$ & \\
$\square$ Decrease & \\
$\square$ Increase & \\
$\square$ No change/very little change & \\
\hline
\end{tabular}

Part III Adaptation to the COVID-19 crisis (can choose more than one)

- Do you have any measures to prevent the COVID-19 spreading?

$\square$ Yes




\begin{tabular}{|c|c|c|}
\hline Question & Answer & Remark \\
\hline $\begin{array}{l}\text { - If yes for last question, what methods } \\
\text { you used? }\end{array}$ & \begin{tabular}{|l}
$\square$ Provide hand wash/alcohol gel \\
$\square$ Provide mask for staff \\
$\square$ Work from home \\
$\square$ Provide quarantine place for staff \\
$\square$ Modify payment to be cashless \\
$\square$ Other, \\
specific...............................................
\end{tabular} & \\
\hline $\begin{array}{l}\text { - Are there adaptation strategy in your } \\
\text { business? }\end{array}$ & $\begin{array}{l}\square \text { Increase selling } \\
\text { opportunities/services/channels, such as, } \\
\text { online, home delivery etc. } \\
\square \text { Temporary modification of products } \\
\text { and services, such as selling masks, gels, } \\
\text { alcohols, or hygiene businesses etc. } \\
\square \text { Change the type of business } \\
\square \text { Attract customers through various } \\
\text { methods, such as, promotion, offer } \\
\text { giveaways, free shipping etc. } \\
\square \text { Reduce salary of employees. } \\
\square \text { Reduce other expenses, such as, } \\
\text { costs, production etc. } \\
\square \text { Sell some assets } \\
\square \text { Other, } \\
\text { specific........................... }\end{array}$ & \\
\hline $\begin{array}{l}\text { - What would you do after the situation } \\
\text { back to normal? }\end{array}$ & $\begin{array}{l}\square \text { Return as normal } \\
\square \text { Return as normal, and improve the } \\
\text { business according to situation } \\
\text { change/pattern/customer behavior/focus } \\
\text { more on online services } \\
\square \text { Adjust the scale of operation } \\
\square \text { Switch to another business instead } \\
\square \text { Cease operation } \\
\square \text { Other, } \\
\text { specific............................ }\end{array}$ & \\
\hline
\end{tabular}

Part IV Accessibility of aid measures

$\square$ Successfully registered and already received subsidies

- Register in the aid project of government $\square$ Successfully registered, but was

- Register in the aid project of government disqualified

$\square$ Registration failed

$\square$ Not register

- Have you received assistance measures $\square$ Yes,

elsewhere apart from the aid project of government?

specific.

- Please specify what you want the government to help you mostly 